\title{
6
}

\section{Pawnbroking and the} survival strategies of the urban poor in 1770s York

\author{
Alannah Tomkins
}

\section{Introduction}

On 9 June 1778 a woman called Ann Moyser visited George Fettes's pawnbroker's shop in York to pledge a checked apron, for which she received a shilling. ${ }^{1}$ On 14 October in the same year, the pawnbroker received a business call from the overseers of St Mary Castlegate parish in York. They claimed that the apron did not belong to Ann but to a parishioner of theirs called Sarah Wood. It is not clear whether the overseers considered the item to have been stolen, lent or pawned by Ann on Sarah's behalf, but they redeemed the apron for Sarah's use without producing the duplicate or ticket which had been issued to Ann in June. Despite this evidence and the sporadic entries in overseers' accounts about pledges redeemed with parish money, pawning by paupers was the exception rather than the rule; the pawnshop was the resort of a large number of people in York, predominantly the labouring poor in times of difficulty, but was rarely used by paupers. Nevertheless a close examination of the pawning practices of customers in general, and a comparison of customer names with the identities of city paupers, illuminates the range of ways pawning was employed and the interplay between pawnshop credit and parish relief in poor household economies. The aims of the chapter are ambitious, particularly given the difficulty of defining or characterising 'paupers'. The poor law might intervene at different points in the experience of households according to local custom, the economic conditions prevailing at different times, and 
the persuasive powers of individuals seeking relief. It would be impossible, for example, to ascribe economic status to people on the basis of the variety or quality of goods they pawned because one household might possess material wealth and receive relief while another might have scanty goods but have avoided technical 'pauperism'.

Such a consideration of the role of pawning in the eighteenth and early nineteenth centuries is long overdue; access to pawnshops and their uses have been largely overlooked by historians of welfare, despite acknowledgement of their crucial role in later periods. ${ }^{2}$ Pawning has been listed among other strategies presumed to impinge on the English 'economy of makeshifts', but with no very clear sense of how it was used to make ends meet; the precise role of the pawnshop has perhaps been peculiarly difficult to determine given the paucity of detailed evidence (an issue discussed briefly in the introduction to this volume). Yet the manipulation of different forms of credit, and the conscious regulation of cash into and out of a household via strategic deployment of material possessions, would appear to be vital considerations in the solvency and viability of labouring families. The aim here is to reach beyond generalities into the specific, minute calculations which kept ordinary people afloat and generated prosperous business for the brokers themselves.

This chapter will look first at public perceptions of pawnbrokers and their likely clientele from contemporary printed sources. A brief overview of George Fettes's career as a pawnbroker in York, and some indication of the economic conditions prevailing in York in the second half of the eighteenth century, preface a detailed consideration of strategies used by customers to exploit pawnshop credit to the full. Finally a study of the income derived from both pawning and parishes by selected individuals gives some indication of the scale and function of the assistance offered by each.

\section{Public perceptions of pawnbroking}

Public opinion of pawnbrokers in the early and mid-eighteenth century was low; descriptions ranged from 'not very reputable' 3 to 'the chief agents of corruption ... the wretches by whom all wickedness is encouraged' ${ }^{4}$ or 'Monsters in the Shape of Men'. ${ }^{5}$ The bulk of published opinion was extremely critical. Meetings 
were allegedly held 'to invent new Schemes to grind the Face of the Poor'. ${ }^{6}$ Doubts about the legality and propriety of living by moneylending, combined with anti-Semitism (given that the image of pawnbrokers was that they were typically Jewish), created a virulent, anti-pawnbroking press. Brokers were accused of using intermediaries such as the servants at bawdy houses, gambling dens and gin palaces to generate business and ruin families; the consequences were marked 'by the loss of life in many cases'. Fielding characterised pawnbrokers themselves as 'Miscreants, which, like other Vermin, harbour only about the Poor, and grow fat by sucking their Blood'. He also echoed the persistent criticism that pawnbrokers frequently acted as the receivers of stolen goods, an anxiety which may have been sharpened by the difficulties associated with convicting receivers in the eighteenth century. ${ }^{8}$ He referred to pawnbrokers's shops as 'fountains of theft', one of the numerous writers who alleged that thieves were encouraged or instructed and employed by pawnbrokers. ${ }^{9}$ Furthermore, pawnbrokers were accused of corrupting the legal system to ensure they were not convicted, via private association. ${ }^{10}$ Even writers posing as independent arbitrators, such as the author of the comments printed in the Gentleman's Magazine in 1745, were often partisan; the writer casually compares pawnbrokers with murderers. ${ }^{11}$ Hogarth's 'Gin Lane' supplied a powerful derogatory image of pawnbrokers, and the picture remains a popular way to represent the terrors of eighteenth-century London life and poverty.

Pawnbrokers were popularly considered to be personally culpable for the uses to which their customers put them. If pawnbrokers were guilty of knowingly lending money on stolen goods then the accusation that they acted as receivers was just, but the practices of the poor in seeking credit were varied and opened up much greyer areas regarding the moral culpability attached to both borrowers and lenders. Writers questioned the integrity of a trader who would lend money to a servant or whore on valuables without enquiry, implying that their guilt lay in their unwillingness or inability to check the provenance of pawns. ${ }^{12}$ Gin-drinking or gambling with money obtained on credit was held to be the fault of the moneylender. A milder but repeated accusation was that brokers accepted pawns from children without their parents' knowledge. ${ }^{13}$ It was in the interest of opponent commentators to imply that the broker rather than the parent was 'at fault'. One 
writer highlighted some injustice with this type of criticism by pointing out that other trades were not held accountable for their customers' actions, citing the example of vintners who are free to sell wine even though people become drunk on it. ${ }^{14}$ Another acknowledged that other traders' prosperity might depend on the supply of ready money to the labouring poor, ${ }^{15}$ but this was a rare reflection in a period when the necessity for pawnbrokers was so often rejected.

Public (published) opinion of pawnbrokers and moneylending altered very little over the course of the eighteenth century. In 1797 Patrick Colquhoun railed against the practice of weekly pawning; typically a working family might pledge tools or other goods on Saturday to redeem their Sunday best, which would be pawned again on Monday morning. He concentrated his attention on the apparently unreasonable profits made by pawnbrokers from this practice (and the folly of 'insuring' in lottery tickets) without considering the alternatives open to the poor who continued to require some 'temporary accommodation'. ${ }^{16}$ In the early nineteenth century, the author of Pawnbrokers Detected and Dissected bundled together 'Usurers, receivers of stolen goods, Jews, and men of the worst principles' as would-be deceivers of the poor. ${ }^{17}$ There was no concession to the idea that the poor in question might legitimately consider pawning to be in their own best interests in the absence of alternative strategies. ${ }^{18}$ The writer viewed the high rate of interest endured by people who frequently resorted to pawning as evidence that 'It is not the really industrious poor that make the most frequent use of these shops.' ${ }^{19}$ The consequences of 'easy' credit were still considered to be drunkenness, crime and suicide. Also pawnbrokers continued to be criticised for the use made of them, especially by people who pawned several times a day (given the proportionately high rate of interest that was charged). The accusation that pawns were taken from children was modified to include the knowledge of parents and complicity of brokers so that the children grow 'lost to all becoming modesty'. ${ }^{20}$

There appears to have been a discrepancy between the type of pawnbroking which attracted intense opposition and the 'honest' trade. The quality of the service provided and the wealth of the clientele who used the shop, the 'tenor of the trade',21 was determined by the goods which were considered to be acceptable collateral and the permanency or ad hoc nature of the business. There may have been pawnbrokers who organised theft and 
burglary but they were not necessarily the majority, or the same as the substantial pawnbrokers who wrote in defence of the practice of moneylending. One alleged convert to the necessity for pawnbrokers claimed in 1745 that people said to be pawnbrokers were really 'people of different professions'. ${ }^{22}$ 'Pawnbroker' was a label which could be applied to any individual who lent money on material security, however slight, and the disreputable "pawnbrokers' caught up in criminal proceedings were claimed to be first and foremost those who took pawns as a sideline (including gin sellers or keepers of disorderly houses). ${ }^{23}$ Another less reputable variation of the pawnshop was the 'dolly shop' which took low-value goods which pawnbrokers would not accept. ${ }^{24}$ In addition, James Lackington claimed that some establishments which advertised as pawnbrokers were in fact simple shops, where customers were over-charged when they thought that they must be getting a bargain in the form of an unredeemed pledge. ${ }^{25} \mathrm{John}$ Styles has found that criminal cases involving people who were described as pawnbrokers were few in comparison to those tradespeople who accepted pawns informally, such as the owners of public houses. ${ }^{26}$

A pamphlet of 1744 rehearsed the arguments or 'apologies' of the 'honest' pawnbroker. ${ }^{27}$ The writer latched on to the then relatively recent example of the failure of the Charitable Corporation to assert that pawnbrokers were the most proper people to fill the role of supplying the poor with small sums. They were represented as substantial businessmen with stock of at least 2,000 items. Also, the pamphlet put the unusual view of the difficulties which pawnbrokers faced in honest trading. If pledges were left for a long time, they were dead stock bringing no return; when sold, they may not bring in the value of the money loaned especially if the clothes had gone out of fashion; in addition, if the goods were sold and the customer later returned to redeem their possessions, the pawnbroker might face a law suit for their full value, 'aided and abetted by pettifogging attorneys'. ${ }^{28}$ If only honest traders were relieved of such threats they could afford to charge lower interest, which (it was alleged) would constitute a genuine benefit to the poor. Furthermore it was argued that pawnbrokers needed to make enough to live and support a family. In fact, the writer of the Apology asserted that the interest charged was not an unreasonable reward for the service provided since if the poor person had to sell their goods instead of pawning them, they 
would not have been able to replace them without considerable loss, much greater than the interest charged by the pawnbroker. It was also claimed that pawnbrokers' return for their investment was modest in relation to the profit made by other traders for smaller outlay and over a shorter time. Many tradesmen had preserved their trade and credit via use of brokers. The pamphlet drew attention to the language routinely used when writing about pawnbrokers, that they 'incur infamy' as a result of the 'opprobrious language freely bestowed'. ${ }^{29}$

In response to accusations that pawnbrokers were in the habit of receiving stolen goods, and thereby gave encouragement to thieves, the Apology asked why more pawnbrokers were not convicted. It was alleged that pawnbrokers only became receivers by accident and even then they were often the one to expose the thief. The writer's resort to hyperbole is some indication of the impact made by past criticism, since he or she claimed that other traders might more easily steal a horse than a pawnbroker might look over a hedge; indeed, as the takers of valuable goods, pawnbrokers were themselves liable to be the victims of thefts. ${ }^{30}$ Anxious to prove their probity, the London pawnbrokers announced their intention in 1753 to take the daily newspaper the Public Advertiser to try to identify any stolen goods presented as pledges and return them to their lawful owners. ${ }^{31}$ A bill of 1752 , which did not become law, had proposed that if a pawnbroker bought goods that had been advertised as stolen they would be guilty of a crime "not yet named'. ${ }^{32}$ John Fielding implied that pawnbrokers did not scan the papers so assiduously as he would have liked when he asserted in 1765 that if SUCH INFORMATIONS are properly attended to ... few Robberies will escape detection'. ${ }^{33}$ An independent voice of support was raised by Campbell in his London Tradesman, where he contended that a pawnbroker's business did not inevitably encourage theft, ${ }^{34}$ but commentators into the nineteenth century continued to allege that brokers did not do their duty and question their customers. ${ }^{35}$

Customers of pawnbrokers who felt cheated in some way by their transactions (and who could afford it) could technically choose to seek legal redress. If the pawnbroker refused to return goods, either because they had been sold or because the customer refused to pay the interest which had accrued, then the customer could bring a suit of trover to recover the value of the goods. Hence the complaint by one pawnbroker that people were likely to bring 
malicious suits to recover the value of the goods without returning the advanced loan. ${ }^{36}$ There seems to have been some justice in the pawnbrokers' complaint in that they were punished for the wrongdoing of others. In 1752 a jury found against a pawnbroker, who had refused to return goods without the payment of money advanced. The fact that the goods had been pawned not by the owner of the goods but by his laundress suggests that the laundress was guilty of theft, but it was the pawnbroker who suffered since he lost both the money loan and the goods. ${ }^{37}$

This example helps to account for their need to associate, to meet the costs of defending such cases (and probably for mutual support in the face of public suspicion and hostility). The legal position of pawnbrokers and their customers was somewhat clarified by an Act of $1757 .{ }^{38}$ This required pawnbrokers to keep a register, detailing the goods pledged, money lent, date and the name and address of the customer. If a person pledged goods on behalf of someone else, the owner's name was also noted. The customer could choose to pay for a ticket comprising a duplicate of the register details. The pawnbroker was obliged to take care of the goods and compensate customers for any loss of value resulting from neglect or wear and tear; however, it also gave pawnbrokers eventual rights over the goods, since items securing a loan of up to 10 pounds were forfeit after two years. There were also clauses to control illegal pawning, such as pledging stolen goods or piecework materials which were the property of an employer. Subsequent Acts sought to define the legitimate activities of pawnbrokers further, for example by stipulating in 1784 the interest which might be charged on loans of different sums over different durations. ${ }^{39}$

There was clearly room for a significant gulf between the public, printed opinion of pawnbrokers and the practical relationships which existed between pawnbrokers and their fellow tradesmen, and between pawnbrokers and customers. The opprobrium to which pawnbrokers were subjected in the press was not necessarily a feature of their everyday experience, particularly where the shop was long established and the business well regulated. Also, commentary focused on London pawnshops. In London, facilities for pawning were ubiquitous and some shops probably did offer a way to dispose of stolen goods. There was considerable scope for anonymity and evasion of the law; indeed in 1794, London was described in one novel as 'an inexhaustible reservoir of 
concealment'. ${ }^{40}$ The situation was different in the provinces. Opportunities for anonymity were fewer, and established pawnshops were more sparsely distributed. By the end of the eighteenth century there were allegedly 431 pawnbrokers in the provinces throughout the country who bought licences, ${ }^{41}$ principally located in substantial towns (pawnbroking being 'an urban phenomenon'). ${ }^{42}$

The provincial picture of pawnbroking, which was relatively unconsidered by contemporaries and has been inadequately studied by investigations into the broad spectrum of welfare facilities, forms the main focus of this chapter. Melanie Tebbutt has demonstrated that in the $1870 \mathrm{~s}$, pawnshops were most prevalent in industrial, manufacturing areas, particularly in Lancashire and the Black Country. ${ }^{43}$ This pattern was already evident by the end of the eighteenth century when pawnbrokers outside London were already clustered in the north-west and the midlands. ${ }^{44}$ Therefore, the evidence supplied by the pledgebook of George Fettes, working in the almost anti-industrial atmosphere of 1770s York, cannot be used confidently as a proxy for patterns of pawning in general. Nevertheless, there was probably little uniformity in the practices of different populations in different regions; even in the late nineteenth century 'industrial pawnbroking was itself hardly uniform'. ${ }^{45}$ An investigation of the surviving pledgebook will at least shed some light on the situation in York.

\section{George Fettes, pawnbroker, and the city of York}

The evidence indicates that George Fettes, the York pawnbroker of the 1770 s, was one of the 'honest' pawnbrokers whose protests of innocence were occasionally heard above the general din of disapproval. He had an established shop in Lady Peckett's Yard off Pavement in the town centre (see figure 6.1). ${ }^{46}$ The surviving pledgebook of 1777 and 1778 is itself the earliest evidence of his business, which was the only pawnbroking firm in York to be listed in the 1781 directory. Fettes was listed with a second pawnbroker, Thomas Palmer of Swinegate, in the Universal British Directory of 1798. Fettes carried on trading until he sold the business at some time between 1823 and 1827 .

George Fettes had been born into a family of substance; his father was an Edinburgh merchant and his cousin Sir William Fettes later founded the Edinburgh school of the same name. He 


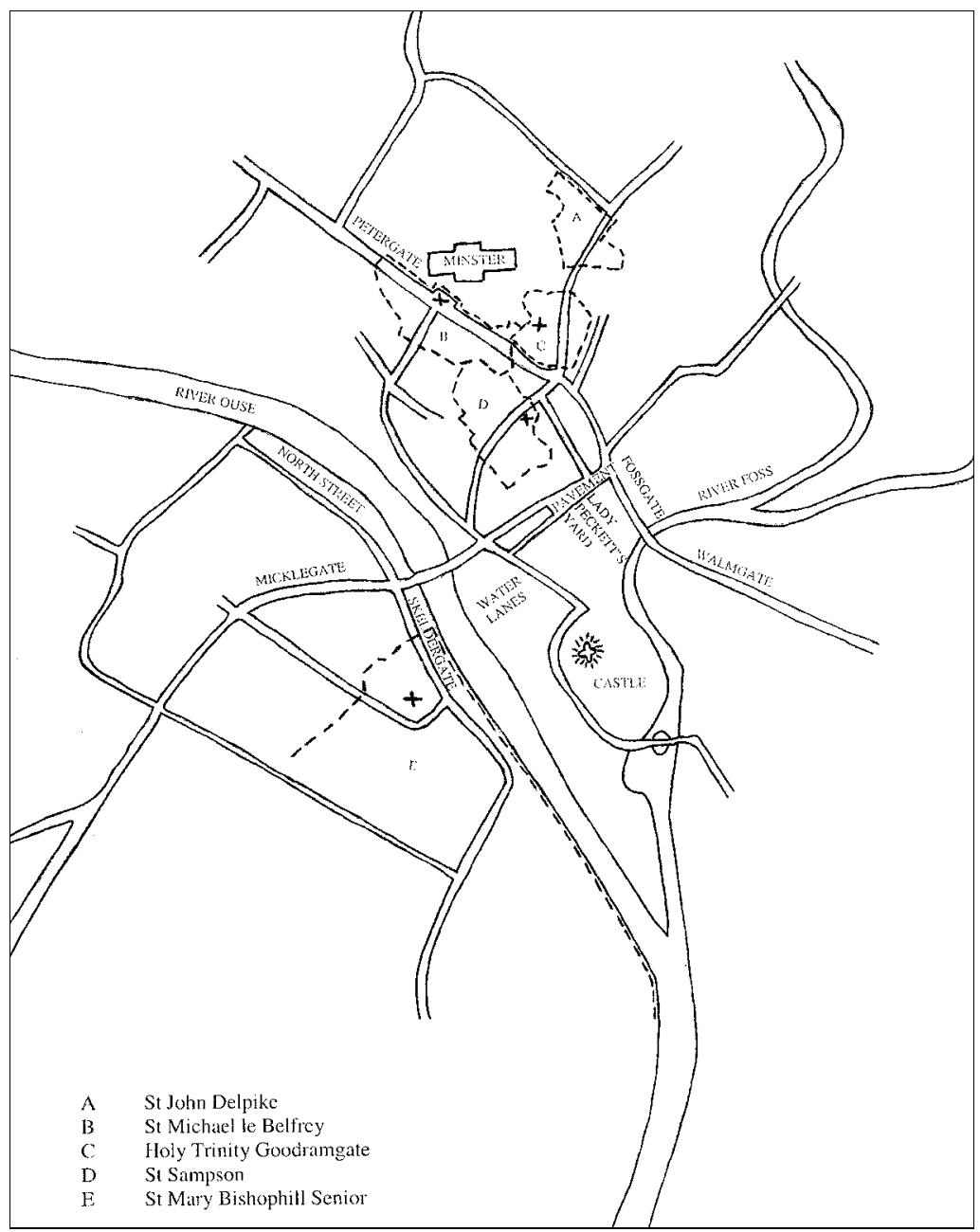

Figure 6.1 Map of York

was a young man in his early twenties during the years when the pledgebook survives; in later years he came to be well regarded by his fellow traders and citizens in York. He was elected a commoner to the city council by 1798 , served as Sheriff for the city in 1802 and thereafter was one of the 24 city aldermen. His financial and trading experience was presumably influential in his being appointed one of the first directors of the York savings 
bank, established in 1816. He and his wife Elizabeth were both Wesleyan Methodists and were valued members of the congregation. George was a 'President of the prayer leaders' and fellow Methodist John Pawson remembered his 'great kindness' at the time of his (Pawson's) marriage in $1785 .{ }^{47}$ Fettes was a friend of John Wesley who stayed with him on his visits to York. The pawnbroking trade clearly did not stand in the way of this relationship, although it may have been the subject of some friendly raillery between the two men. In Wesley's only recorded letter to Fettes he wrote 'Prove these two points - first that pawnbroking is necessary, secondly that it is lawful (in England) - and you will satisfy your affectionate brother John Wesley.' ${ }^{4}$

York might be eligible for the 'leisure town' status accorded to Shrewsbury. In the early eighteenth century Defoe referred to York as a place of 'good company and cheap living; a man converses here with all the world as effectually as at London' but enjoying 'no trade indeed, except such as depends upon the confluence of the gentry'. ${ }^{49}$ In 1745 he was echoed by another commentator: 'the chief support of the city, at present, is the resort to and residence of several country gentlemen with their families in it'. It has been described as the social and intellectual capital of the north between the seventeenth and the nineteenth centuries. ${ }^{50}$ Nevertheless, by the 1770 s not all of its visitors thought it a particularly vibrant social centre. One of Horace Walpole's correspondents described it in 1771 as 'this dullest of all provincial towns'.51

In the 1770 s the city of York's population was gradually increasing, since the inhabitants numbered approximately 12,000 in 1760 but had reached 16,145 in 1801;52 however, York did not experience any of the economic upheaval associated elsewhere with industrial development, technological change or reorganisation of employment. This was considered by contemporaries to be a result of 'the restrictive policy of the corporation' which tended to discourage outside manufacturers from settling in York. The corporation attempted to enforce the freedom regulations strictly throughout the eighteenth century; it was still being urged to 'open the gates to all tradesmen and manufacturers inclinable to settle among us' in $1790 .{ }^{53}$ York's chief economic importance remained its role in the regional economy, as a centre of wheat and dairy distribution. This remained true well into the nineteenth century, despite relatively rapid population growth after $1800 . .^{54}$ 
Coincidentally, York had been a notable centre for moneylending in the sixteenth century, but this function had seemingly declined in importance well before the $1770 \mathrm{~s}^{55}$

The absence of any significant manufacture in the city was cited by one contemporary as a significant cause of the distress of the poor; the experience of poverty caused by people's 'life-cycle' was exacerbated by restricted employment opportunities. Nevertheless the picture of York presented by the evidence of formal relief was unremarkable. The number of paupers in York was around 500 in the $1720 \mathrm{~s}$, amounting to around 5 per cent, a typical proportion of urban populations. ${ }^{56}$ The poor were managed by individual parishes, of which there were 28 in 1777, but overseers of the poor were supervised by the corporation which compiled statistics relating to poor rates and expenses in a central 'Poor Book'. Proposals to found a workhouse were considered in 1729 and 1737-39, but schemes to cover the whole city failed. In 1768 several parishes chose to unite for the purpose of running a joint workhouse which was established in Marygate, but individual parishes continued to administer their own funds and to pay outdoor relief. ${ }^{57}$

In addition to rated relief, inhabitants of York parishes could claim assistance from a relatively long list of privately-funded charities which provided almshouses, cash for apprenticing and other benefits. It was claimed in 1833 that the wealth of charities in some parishes made them particularly desirable as places of settlement; parents prevented children from taking apprenticeships if it meant they would lose a settlement in a parish with munificent charities, and outsiders would strive to acquire settlements in such places. $^{58}$

Finally, as Armstrong has observed, York was to become the focus of Rowntree's influential report on poverty at the end of the nineteenth century, making it an intriguing subject for the study of poverty in earlier periods..$^{59}$

\section{Pawnshop customers}

George Fettes held a key position in this framework of urban development and the experience of poverty. He kept a pledgebook recording customers and their pledges in accordance with the law of 1757 . He or his shop assistants recorded the date, the name 
and address of customers, the goods pledged and the sum advanced. If the items were redeemed the date of redemption was commonly entered but the source is faulty in that notes of redemptions become more rare towards the end of the volume. On the last day when the book was used to enter pledges, 26 December 1778 , no redemption dates were written down, presumably because it was too much trouble to look up the initial entry in an old book once a new book was in use in the shop. One redemption after December 1778 was noted, because the customer waited six years to collect his goods: George Parrott, after pledging his silver watch during York race week on 22 August 1777, only came back for it on 29 May $1784 .{ }^{60}$

A simple statistical breakdown and analysis of this very rich source sheds new light on the place of pawnbroking in the lives and strategies of the urban poor. Fettes received a total of 10,879 pledges in the eighteen months from July 1777 to December 1778. The pace of business fluctuated according to the weekly, monthly and annual requirements of customers but also according to Fettes's willingness to loan money; the book only records loans made rather than loans requested. The number of pledges accepted (Figure 6.2) fell from an average of 33 a day in February 1778 to a low of 17 in July 1778. The possible causes of this downturn in trade include the appearance of a trading rival or an improvement in the financial fortunes of York's labouring poor. ${ }^{61}$ The economic complexion of the two years 1777 and 1778 was very different and it is likely that increasing hardship had some part to play in making Fettes more reluctant or less able to accept pledges. In 1777 England enjoyed something of a boom; the Yorkshire woollen cloth industry enjoyed considerable prosperity, with the output of broadcloth increasing. ${ }^{62}$ Admittedly the harvests were good in both years ('prodigious' in $1778^{63}$ ), but the crucial difference between the years was caused by the entry of the French into the American War of Independence. Britain had been at war with the American colonists since 1775, but French involvement raised the stakes and intensified the British effort. Consequently, there was a hike in taxation rates and financial crisis threatened. Ashton's analysis of contemporary statistics and comment identifies 1777 as a peak of prosperity, with signs of decline in late 1777 , and sudden crisis in the first months of $1778 .{ }^{64}$ The construction industry suffered a serious depression 1778-84, a common feature of wartime in the eighteenth century, and the 
Yorkshire cloth industry experienced a sudden depression. It was said that 'trade of every kind seems to be at a perfect stand owing to an uncommon great and general scarcity of money' and there were 623 bankruptcies in 1778 as opposed to 471 in 1777 . The rate of custom at Fettes's shop suggests that he initially responded to this sudden demand for money by meeting customers' requirements but was limiting his advancement of credit later in the year. Either he was suffering himself from the shortage of money and unable to take advantage of his customers' desire for cash, or he became more cautious about making loans, fearing that if redemptions were sluggish he would be left with a large, unprofitable, perishable 'dead stock'.

The weekly pattern of pawning is clearly visible from the database. Customers were most keen to pledge their property on Saturday or Monday, with these days seeing 23 per cent and 21 per cent of business respectively. The remaining pledges each week were shared between the other four working days. This broad pattern conceals a wide variety of usage by different types of customer. Some people only entered the shop once during the eighteen months covered while others might visit several times a day. One strategy employed by customers was to pledge several items at the same time but in separate lots and redeemable on separate tickets. This meant that goods could be redeemed one at a time although it did mean buying a ticket for each pledge. On 2 October 1777 Henry Richardson made eight pledges of individual items of clothing for between three and six shillings each; he redeemed them over the next ten months, between 1 November 1777 and 22 August 1778.

In addition to the pledges made by customers the book contains the dates when goods were redeemed. Analysis of a small sample of redemptions (for two weeks in September $1777^{65}$ ) showed that the average time lapse between pledge and redemption was 56 days, but this bland average conceals three basic types of behaviour in pledging and redemption by customers. Half of all pledges were short term, with a quarter destined to be redeemed within one week and another quarter collected within a month. The majority of the remaining items stayed in the shop for longer periods of 29 days or more. On 3 September 1777 Frances Smith pawned a brown calamanca gown for $4 \mathrm{~s}$. and returned for it nearly a year later on 31 August 1778. Some goods were never redeemed; 14 per cent of pledges left with Fettes went unclaimed. It was 


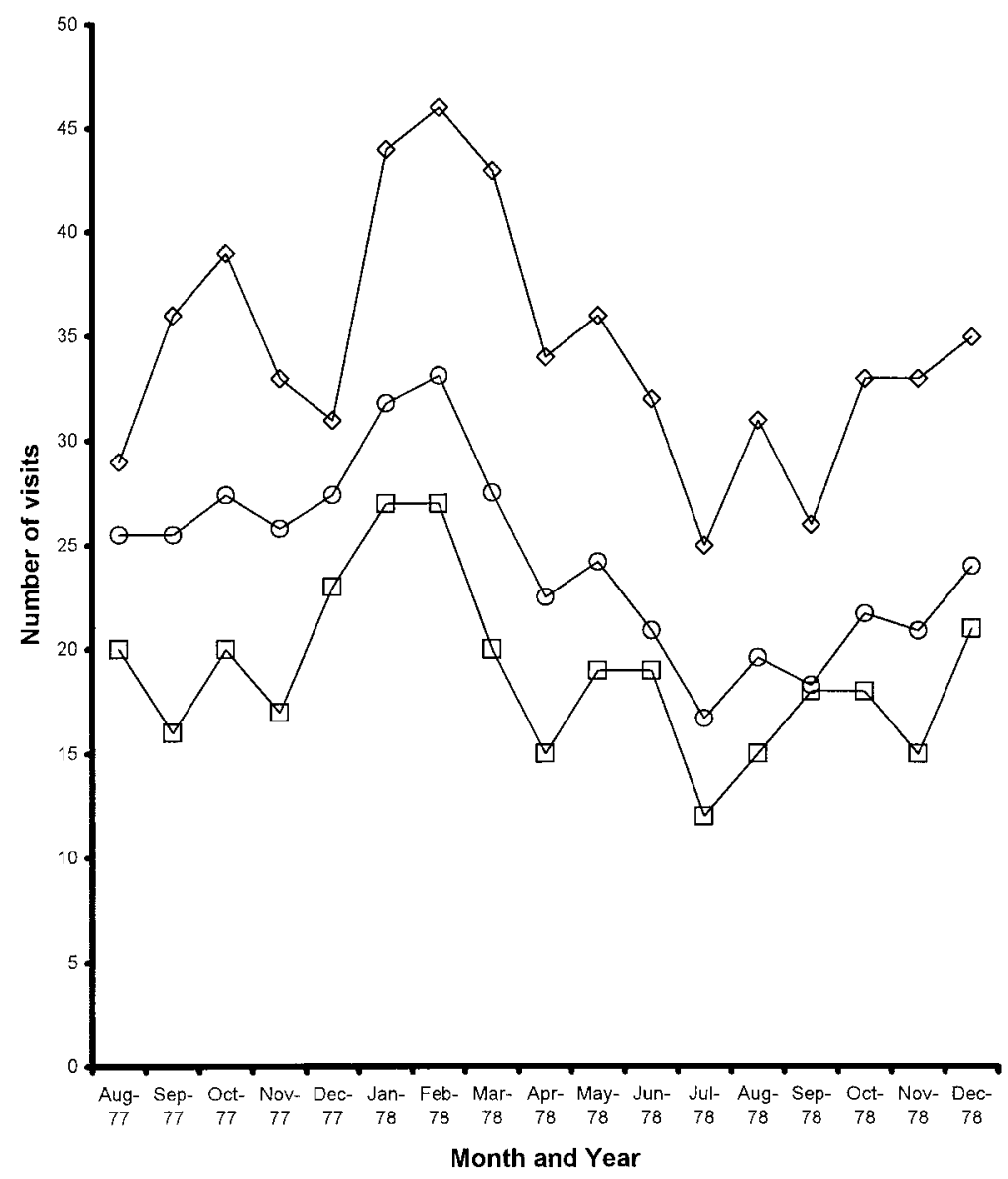

$\multimap$ Overall/monthly avg $\square$ Fri avg $\diamond$ Sat avg

Figure 6.2 Pledges accepted by George Fettes

asserted in the Gentleman's Magazine in 1745 that many items were considered unlikely to be redeemed if left with the pawnbroker for more than 15 months. Therefore, items pledged in September 1777 and not redeemed by December 1778 could be assumed to have been abandoned by their owners.

It is difficult to trace the weekly redemption pattern of goods since this requires a calculation of what weekday the date of redemption fell in the case of each individual pledge. Also, the 
record of redemptions is incomplete since goods pawned before July 1777 could have been redeemed at any time without a record surviving; however, there is no particular reason to suppose that the pattern of redemption for goods not listed in the surviving book was different from any sample of redemptions that are listed. This analysis revealed that Saturday was by far the most popular day for redemptions, with 30 per cent of pledges being collected. Monday was the next most popular day, but only accounted for 14 per cent of redemptions. This is what might have been expected. Presumably, Saturday was pay day for many of the working population in York and therefore the day when people were most likely to be able to redeem pawned goods.

The amounts of money advanced for pledges were usually considerably below their 'value' to their owners, but may have represented little less than the pawnbroker could have hoped to make by their sale. Fettes only occasionally recorded the sale of goods; there were two lone entries of goods sold during the first two weeks of September 1777 out of 236 pledges. Where he also recorded the amount he received for the sale, it does not seem to indicate a particularly high profit margin. In November 1777 he sold a gown for 10s. 6d. which had been pledged for 9s.; he may have gained less from this sale than he would from the payment of interest by the owner.

The smallest sum Fettes lent in 1777 and 1778 was 2d. and the greatest 10 guineas. ${ }^{66}$ The average loan over the whole period was $3 \mathrm{~s} .9 \mathrm{~d}$. but the majority of loans totalled $2 \mathrm{~s}$. or less. ${ }^{67}$ The average amounts loaned rose significantly in August each year at the time of the races (the main focus of the York social season); 68 in the seventeen months August 1777 to December 1778 the average amount loaned on each occasion was between $3 \mathrm{~s}$. and $4 \mathrm{~s}$. during twelve of the months but rose to $5 \mathrm{~s} .5 \mathrm{~d}$. and $4 \mathrm{~s} .10 \mathrm{~d}$. in August 1777 and 1778 respectively. Visitors to the town were among Fettes's wealthier clients, able to pledge more valuable goods. William and Thomas Bradley of Newton on Derwent both pledged their watches in August 1777 and Thomas also pledged his greatcoat, coat and waistcoat. Thomas literally lost the coat from his back and the Bradleys both had to wait until a return trip to York in November to redeem their property. ${ }^{69}$

Most of the goods which Fettes accepted as pledges could be characterised as items of adult clothing, but he also routinely lent money on soft furnishings, household metalware such as irons and 
cutlery and more valuable pieces such as watches and jewellery. ${ }^{70}$ This is the pattern repeated in evidence of nineteenth-century pawnbroking and this aspect of pawnbrokers's business has been used to illustrate the vibrancy of the second-hand clothing trade in the eighteenth century. ${ }^{71}$

The predominance of women's clothing, particularly aprons and gowns, reflects the gender balance of Fettes's clients. Women represented the majority of his customers, and made more repeated visits than men (suggesting a central role for women in northern household economies). During the sample two weeks in September, the most frequent male customers each visited the shop three times. By comparison, twelve women visited the shop on four or more occasions and Sarah Beeforth made pledges at 15 different times (more than one pledge per day when the shop was open). A database of customers' names ${ }^{72}$ was edited and condensed to derive a guesstimate of the number of individual customers who visited Fettes's shop between 18 August 1777 and 26 December 1778 (see appendix, pp. 192-3). This guesstimate gives 2,200 people of whom 1,349 or 61 per cent were definitely women. This is a somewhat lower figure for female customers than might have been expected given that women were more likely than men to be counted twice in making the guesstimate. Women who married and therefore changed their name during the eighteenth months of the pledgebook would inadvertently have been counted twice. The total figure of 2,200 suggests that, in a town of 12-14,000 people, 15-17 per cent of the population resorted to this pawnbroker and had pledges accepted. ${ }^{73}$

The pledging of clothing and household goods by women to raise credit supplies circumstantial evidence for an overlap between the pawning poor and those guilty of theft. The same sorts of goods were the most popular targets for both male and female thieves but were disproportionately stolen by women who were also more active in pawnshop transactions than men. It is likely that this overlap (which may or may not have arisen from a causal connection) exacerbated public suspicion of pawnshops. Confusingly, in late eighteenth-century London the connection between pawnshops and theft was drawn explicitly when women pleaded not guilty to theft, on the grounds that they had pawned goods on behalf of others or with permission rather than as a strategy for converting stolen property into cash; 'these were instances of women's borrowing networks gone wrong'. ${ }^{74}$ 
The York evidence can only show that overt borrowing, or pawning on behalf of others, was not very common. The law of 1757 required Fettes to keep a record when goods were pawned by one person on behalf of another, and there are only 52 instances of this practice between August 1777 and December 1778 accounting for only 0.5 per cent of all pledges. Also, there is no discernible pattern to these pledges for others. People may have been acting on behalf of friends, relatives, employers or tourists staying locally. Twice in 1778, pledges from John Hare were brought by Nurse Hare, presumably a relation, whereas items belonging to Mrs Wood of North Street were brought by Mrs Aspinall of Petergate (addresses at some distance from each other). Catherine Woodhall of Thursday Market sent her apprentice to the shop with four silver teaspoons on 29 August 1777 but never came by to redeem them. Robert Hepworth, who was staying at Judges Lodgings, persuaded (or paid?) Widow Aldridge, an almswoman who was otherwise a stranger to the pawnbroker's, to take a coat, waistcoat and silk gown to be pledged. Presumed cases of borrowing are occasionally discernible, where the same item (such as a watch identified by a manufacturer's number) was pledged more than once by two or more different people, but it would be impossible to trace anonymous items (such as most clothes) moving between pawnshop customers.

Customers were mainly drawn from the city of York itself, with tourists being the exception rather than the rule. Assuming the list of 2,200 people to provide a fair reflection of the individuals involved, the largest contingent came from Walmgate and North Street, locations on the south side of the city a little way distant from the centre. Between 2 and 5 per cent of customers were drawn from each of Fossgate, Goodramgate, Petergate and Micklegate, large thoroughfares leading into the city centre, and from the Waterlanes and Skeldergate, poor areas on the banks of the Ouse. Other addresses accounted for fewer than 2 per cent of all customers. This picture is broadly in line with a study of addresses taken from pledges rather than separate customers. ${ }^{75}$ It suggests that customers were drawn to the shop regardless of its distance from their homes. People may have been drawn in by its proximity to their place of work or to places where ready money might be spent such as gambling dens or alehouses (one of the greatest fears of the anti-usury pamphleteers), but it is more likely that the need for cash drove people to walk any necessary distance. 


\section{Paupers and the pawnshop}

The paucity of sources like Fettes's pledgebook has led to a neglect of pawnbroking as an alternative strategy for the eighteenth-century poor; the subject has received more attention for the nineteenth century. During the latter, Treble found that pawnshop credit was obtained for four different types of need; access to short-term (often weekly) credit, seasonal pawning to cover longer periods of difficulty, pawning to pay for costs associated with sickness such as doctors' bills or loss of earnings, and steady pawning in periods of unemployment. Yet it is important to distinguish between all people who had desperate need of credit and the individuals best placed to obtain it from pawnbrokers, since there were different gradations of poverty. Pawnbrokers were most accommodating for clients with regular wages and were wary of unemployment. ${ }^{76}$ Beverley Lemire has rightly observed that pawning in the eighteenth century 'was not restricted to the indigent, to the destitute, or to the recipients of charity'. ${ }^{77}$ In fact the services of the reputable, established pawnshop were virtually denied to the destitute because, as in the nineteenth century, 'there were certain sections of the working classes who were treated as unacceptable risks'. ${ }^{78}$ There was a reduced chance that they would be able to redeem their goods and pay the interest, leaving the broker with their (typically) low-value goods. The destitute were compelled to turn to dolly shops, or moneylenders requiring little or no security, where the rate of interest was even higher. ${ }^{79}$

Commentators in the eighteenth and early nineteenth centuries who deplored the practice of pawning tended to demonstrate a masterly lack of understanding of the cash-flow problems of the labouring poor. Until the end of the eighteenth century, ${ }^{80}$ writers were largely unaware of the intimate minutiae of poor household budgets but relied instead upon suppositions formed from a position of relative financial security. It is notable that writers were invariably men enjoying relative financial security whereas pawnshop customers were typically poor women. Such views were (justifiably?) said to demonstrate 'Ignorance of the Sudden and Unexpected Disappointments and Embarrassments, which not only People of the lower Rank, but even those of a higher Station are liable to'. ${ }^{81}$ Occasionally a more balanced independent view was available. The assertion 'the industrious poor could as well do 
without butchers, bakers and brewers, as they could subsist without some such conveniency of borrowing money' was reported second-hand and not wholeheartedly endorsed by the writer, ${ }^{82}$ but Campbell stoutly declared 'they are so necessary to the poor ... I cannot comprehend almost how they can live without the Pawnbroker'. ${ }^{83}$ Those who wrote actively in defence of pawnbroking described the clientele of pawnbrokers as 'chiefly among the industrious poor, and working part of mankind, who have little or no credit at all, and who, for want of some such assistance, must come upon the parishes they belong to, or be starved'. Pawnbrokers were characterised as providing much-needed assistance in the period between the onset of a crisis and a resort to the parish, and preventing people from falling on rates and this view received inadvertent confirmation in other texts. ${ }^{84}$ Such writers correctly perceived pawning as typically an alternative expediency to parish relief, not an auxiliary service.

The process by which individuals or households fell into utter destitution (a state partly defined by a scarcity or absence of any goods to sell or pawn) could be lengthy and the pawnshop could be crucial to this process. In addition to providing access to credit, pawning without redemption was an obvious way for people's material stock to decline. Yet (as I mentioned in the introduction to this chapter) parishes could intervene at different points in the process for different people. Any group of people on parish relief might encompass a wide range of material wealth, from those rich in goods to those who had reached destitution. ${ }^{85}$ This means that very few assumptions can be made about people identified as paupers without additional information about the point they have reached in the process of destitution. The only thing that can be said about them is that they are sufficiently needy to have attracted the attention of the poor law authorities, for which the threshold could be relatively or surprisingly high in terms of material wealth.

The number of Fettes's customers who were also in receipt of parish relief is few. In order to find paupers among the pawnshop customers, I compiled the names of the poor receiving some kind of parish relief during the years 1777 and 1778 in the parishes where overseers accounts survive for these years. The five parishes with good accounts are St Michael le Belfrey (the parish with the largest population in York in 1801), St Sampson, St Mary Bishophill senior, St John Delpike and Holy Trinity Goodramgate. These parishes contained 20 per cent of the town's population in 
1801 , so if pauper customers were drawn from parishes in proportion to the total population, any overlap between known paupers would represent 20 per cent of the total number of pauper customers. Unfortunately, it is unlikely that paupers were drawn from parishes in proportion to the total population because some areas of the city were poorer than others and more likely to be home to customers; the number of pauper customers found is likely to underestimate the total because some of the most popular addresses for customers fall in parishes with no surviving overseers' accounts.

A total of 201 paupers were found receiving parish relief in 1777 and or 1778 , of whom 16 were deemed to be customers from a correspondence of names and addresses. A further 38 paupers may possibly have been customers but there was some inconsistency between the pauper's name and address and that of the customer. This gives a total of 54 people who might have been both paupers and customers. Taking only probable individuals, and assuming they represent 20 per cent of all probable pauper customers, then only 4 per cent of Fettes's customers belonged to the parish poor. If the 'possibles' are included then the total rises to 12 per cent. Even if this underestimates the total extent of overlap between paupers and pawnshop customers by half, then over three-quarters of Fettes's customers were not paupers at approximately the same time they made use of his shop. However, it is likely that many more customers would technically become paupers over the course of their life-cycle, given the gradual, incremental nature of the process of decline into destitution.

In finding pauper customers, some were easier to identify than others. For example, the overseers of St Michael le Belfrey paid relief to Joseph Armitage's wife, so it was legitimate to look for both Joseph and Mrs Armitage of Petergate in the pawnbook; in contrast, there were a number of customers called Turpin who may have been related to one another, but it was only legitimate to collect references to Jane Turpin from the overseers' accounts since she was the only pauper named.

There are a couple of references in the overseers' accounts to goods redeemed by the parish during 1777 and 1778. In 1778 the overseers of St Michael le Belfrey paid to redeem from pawn clothes belonging to Mary Wilson's child, and paid twice to redeem the clothes of Elizabeth Gleddill's child. These clothes may have 
been placed with Fettes before the start of the surviving pledgebook, because there is no record of them being pawned. Alternatively, this is a fragment of evidence that paupers (or some individuals among paupers) had access to credit from some other source, possibly some less reputable moneylender than Fettes, who required less in the way of security and more in the way of interest.

Parish officers had an interest in monitoring the disposal of goods by paupers because parishes occasionally decided to appropriate material possessions when paupers entered the workhouse or died. Their authority to do so was wholly assumed (it was not authorised by law) and was not always exercised. ${ }^{86}$ Entries in parish accounts to a person's goods being carried to the workhouse, and becoming subsumed into parish property in subsequent inventories of workhouse property, or the acknowledgement that a portion of parish income derived from the sale of paupers' goods, is the only (sporadic) evidence for the practice. ${ }^{87}$ It was presumably easier for parishes to assume ownership where a pauper died without dependents or local kin to assert a claim to whatever scanty goods remained. In Leeds, paupers were periodically forced to surrender their goods when entering the workhouse, a strategy on the part of the parish which increased the severity of the 'workhouse test' and reduced the number of relief claimants. ${ }^{88}$ In Mansfield the workhouse rules required every inmate to bring their goods and chattels with them, although this may not have been consistently enforced. ${ }^{89}$ There was a similar condition attached to workhouse entry in Lincoln, but there paupers could take their goods away with them again if and when they left. Claiming pauper goods for the parish may have been only an occasional strategy to defray some of the costs of keeping a person over the preceding years, but it suggests an element of self-interest in parish scrutiny of pauper possessions and their disposal by pawning or other means.

An associated problem for parishes (and also for charities and other agencies which supplied free clothing or access to household goods) was the illegal pawning of parish goods by paupers for their private gain. In some places, the parish 'mark' was fixed to clothes, household wares and even furniture to prevent or inhibit their theft and subsequent disposal. Such a strategy presumably made it easier for parish officials to identify goods and for reputable pawnbrokers to avoid the charge of receiving stolen goods; it was not a guarantee, however, that theft would not occur.

Individual people used the pawnshop in different ways but the 
variety of their usage was not decidedly conditioned by whether they were a pauper at the same time. All types of customers employed a number of different strategies in maximising their use of the pawnshop. The only identifiable difference between pauper customers and all customers was that paupers on average redeemed their goods much more quickly; on average customers repaid their loan after 56 days whereas paupers took an average of only 25 days. It is difficult to know what to make of this given that each average conceals such a wide range of behaviour. It may possibly suggest that the poorer people became, the more shortterm their strategies or the more central the pawnshop became to their survival.

The main obstacle to determining patterns of use by different types of customer lies in the difficulty of categorising individual customers as representatives of the independent labouring poor or as parish paupers; I could not be certain that a customer who was not a pauper in one of the five parishes studied was not a pauper in one of the other 23 parishes listed in the 1777 overseers' returns to parliament. Individuals are also indistinguishable as members of a particular trade or as domestic servants since there are very few occupational labels recorded against customers' names. Also, there was virtually no overlap between the tradesmen listed in the York directory of 1781 and the pawnshop's customers..$^{90}$ It was said in 1745 that it would be injurious for the reputation of a trader even to enter a pawnbroker's shop; tradesmen who were tempted to pawn were advised instead to admit their virtual insolvency. ${ }^{91}$ If there was a stigma for tradesmen in approaching a pawnbroker they might have tried to use intermediaries, but such a practice is not disclosed by a study of the few items reported to have been brought on someone else's behalf.

One of the only identifiable groups of customers is the almsmen and women who lived in one of the many almshouses or 'hospitals' in York; at least 19 were operational in the 1770s. ${ }^{92}$ Almspeople are recorded amongst Fettes's customers by virtue of their address being given as the almshouse; however, only 13 men and women are listed in this context, seven of whom only used the pawnbroker once or twice and none of whom visited more than 13 times. A number of the almshouses paid a stipend to inhabitants in addition to providing accommodation, so these charity recipients could rely on a regular 'wage' or income. The infrequency of their custom suggests either that this rendered them less liable to the sudden 
need for credit, or that the regularity of their income did nothing to persuade Fettes to accept their pledges. The few charity customers there were seemed to use the pawnshop for very long-term credit, since their average time before redemption was 67 days, much longer than paupers and even longer than the average for all customers of 56 days.

It is not possible to compare the use made of Fettes's shop with Treble's categories of the reasons why credit was sought. For instance, it is likely that a number of the customers in York did need a short-term loan as a result of illness, but it is not now possible to determine which individuals became involved in this way. It is possible to look at some of the patterns of custom, which are critical to understanding the experience of poverty which did not fall within the scope of formal parish agencies. There were people who only used the shop once or twice during the period covered by the pledgebook. Pendock Vane or Vame, apprentice to the barber-surgeon John Firth of Coney Street, pawned a silver watch on 18 July 1777 and redeemed it on 4 November of the same year but did not place any further pledges before the end of the volume. ${ }^{93}$ Others came in periodically over the eighteen months, perhaps on a monthly basis but not necessarily to a predictable pattern. Ann Plaister's address was 'Mr Telford's Nurseryhouse'; she was presumably an employee of John and George Telford, seedsmen with premises in Tanner Row. ${ }^{94}$ She made eight pledges in September 1777, a further three in October and she reappeared periodically over the following months. She can be found pawning twice in the final week for which the book applies in December 1778. Some customers used the shop intensively over one or two months and then slackened off, or did not reappear in the book. An example of this sort of usage, which might best be characterised as episodic, is provided by the Beeforths who lived in the Shambles. Sarah Beeforth visited the shop 15 times during the first two weeks in September 1777, pledging various items of clothing and shoes. One pledge was redeemed the day after it was pawned, while another remained in the shop until the following March. She visited the shop between three and six times each week for the following seven weeks. During the fifth week Elizabeth Beeforth also of the Shambles and possibly a member of Sarah's family and/or household appeared as a customer. In the seventh week Richard Beeforth of the Shambles made pledges; there is circumstantial evidence that Sarah and 


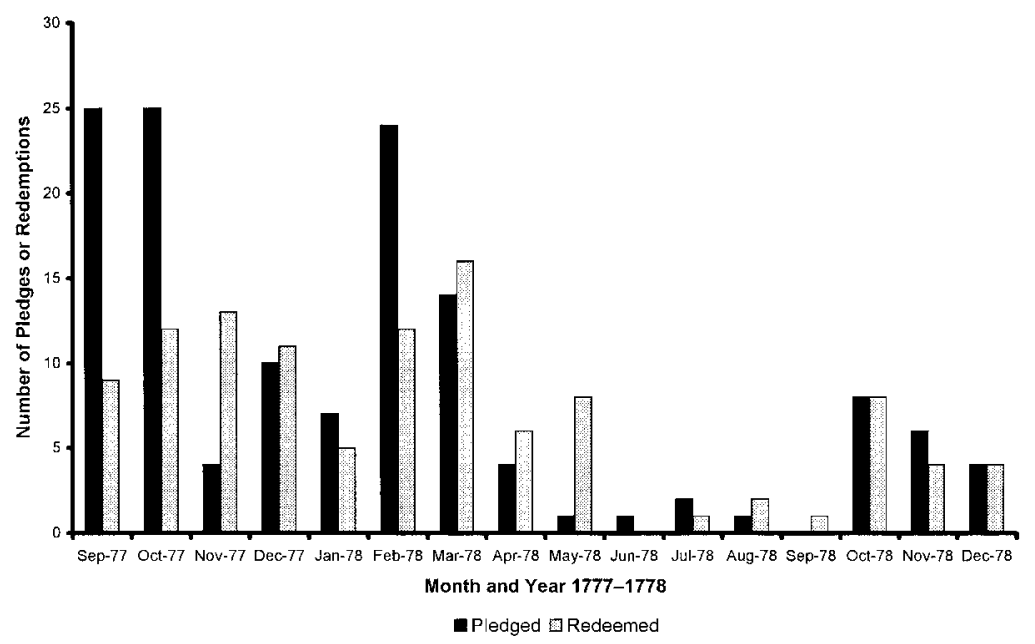

Figure 6.3 Pledges and redemptions by the Beeforth family

Richard were connected in some way because they both pledged items used in patten-making. On 8 October Sarah pawned a patten-maker's knife which remained unredeemed in December 1778 while Richard pawned four pairs of patten irons on 1 November and redeemed them on 8 November. After the end of the seventh week (Saturday 1 November), the Beeforths were obviously better off, redeeming more goods than they pledged in November (Figure 6.3). They remained occasional customers until their next period of particular difficulty in February 1778. From March to May they were net redeemers, and then made only a handful of visits to the shop until October; up to December 1778 the shop experienced a small concentration of custom from them, which was trailing off by the end of the year.

The sheer number of customers, the doubts about whether an individual listed on one occasion was the same person recorded on another day (with a slightly different spelling for their name, or a different address), and the fact that it is difficult to determine whether people lived with or were related to one another, makes it impossible to know whether there were more complex patterns of credit-seeking at work in York's poorer households. Nevertheless, the broad picture of pawnshop use illustrates these three patterns at work. There were many people who visited the shop only once or twice, but the majority of pledges are accounted for 
by people who either pawned periodically throughout the months covered by the pledgebook, or who needed to pawn intensively over a shorter period of weeks or months.

The advantage in identifying people who were quite probably both pawnshop customers and paupers lies in the use of the two sets of accounts to observe the combination of the two sources of income. A close examination of overseers' accounts in conjunction with the pledgebook reveals that nine of the sixteen paupers used the parish and the pawnbroker consecutively; most pawned goods up until the point they received parish relief but a couple worked the other way round and pawned once they were off the parish. The remaining seven obtained money from both sources concurrently. The evidence points to a situation where people might make extensive use of one facility or the other since there were no instances which could be found of paupers receiving regular relief who routinely made pledges.

Mary Budd and Mary Prince are both examples of customers who used the pawnshop energetically, if in very different ways. Mary Budd used the shop before she took relief. She worked systematically, pledging a large, fairly fixed bundle of goods on a monthly basis. She pledged her four gowns, her two black satin cloaks and a long list of other goods on the same ticket, left them with Fettes for about a month, and redeemed them only to pledge them again later the same day or the next day. She did this ten times between September 1777 and July 1778 (and made smaller pledges on four other days). She received between $£ 4$ and $£ 5$ pounds for her bundle; $£ 5$ in September 1777 which dropped down to a low of $£ 3$ and 15 s. in July 1778. Fettes was being shrewd in dropping the amount he would advance on her bundle; he also began to insist that the bundle would be forfeit if she did not redeem it within one month. Whatever resources she was able to utilise monthly to redeem her clothes, they ran out after July 1778. The bundle was pledged for the last time on 31 July 1778 and shortly before Christmas she became a pensioner in the parish of St Sampson receiving 2s. per week. Mary Prince was a much more frequent visitor to Fettes's shop, pawning between one and thirteen times a month, making 112 visits between 19 August 1777 and 5 December 1778. She pawned adults' and childrens' clothes, flat irons and a Bible on one occasion for small sums ranging between $4 \mathrm{~d}$. and $3 \mathrm{~s} .6 \mathrm{~d}$. A handful of items remained unredeemed by December 1778 and some items were left for long periods of 
three months or more but the majority of her pledges were redeemed within ten days. She fell into difficulty towards the middle of November 1778, went to St Sampson's parish for help and was given a shilling a week for four weeks.

The Armitages were relatively unusual because they received their relief first, before they needed to pawn, but Joseph Armitage and his wife were only on the fringes of pauperism since they received just a single handout of $3 \mathrm{~s}$. in 1777 and no relief in 1778. They pledged clothes and bedlinen with Fettes on seven occasions between January and September 1778 and redeemed the earlier pledges between March and September 1778, but by December 1778 their last three pledges, including a gold ring, remained unredeemed. An alternative picture is presented by Robert Turner. He was a pensioner in St Mary Bishophill senior parish receiving 4s. per week from November 1777 onwards; he only visited the pawnshop once, on 9 April 1778, to pledge a green silk waistcoat for $4 \mathrm{~s}$. $2 \mathrm{~d}$. He collected it on 2 July and apparently did not return again.

\section{Conclusion}

The case of George Fettes provides the opportunity to test the operation of provincial pawning in the context of a hostile, critical press which tarred all pawnbrokers with a metropolitan brush. He was a respected businessman with a vibrant trade which stretched from the tourist visitors who came for the races to the poorest inhabitants of York's streets and alleys. Furthermore, the pledgebook supplies vital information about the experience of poverty in York. The routine finding that approximately 5 per cent of the population stood in need of parish relief is given context by the fact that 15-17 per cent of the town's inhabitants made use of this one pawnbroker in the relatively short period July 1777 to December 1778. Different styles of usage can be identified among Fettes's clientele. Customers might use the shop once, possibly pawning a single valuable item, to help them cope with a particular crisis. Others used the shop persistently but not necessarily frequently to deal with periodic, recurrent problems or shortfalls. Brief periods of intense pawning followed by a lull in activity or disappearance from the pledgebook can be labelled episodic, emanating from a period of crisis which either permitted 
short-term recovery or signalled an important stage in absolute material decline into destitution (and thereafter an absence of goods to pawn). The role of the pawnshop in the process of either independent survival or decline into dependency can be charted, particularly in the case of individuals who went on to receive parish relief. The strategies employed by the poor who dealt with Fettes's pawnshop were limited by whether he was willing to accept their pawn, by the amount he advanced, and by their ability to redeem their goods. Nonetheless, individual people exploited the essential flexibility of pawning to cover routine expenses, regain their financial equilibrium following a crisis, or stave off deeper destitution for so long as their material wealth would allow.

\section{Appendix}

The names attached to over 10,000 pledges were conflated to give a guesstimate of the number of individual people who made use of the pawnshop during the period 18 August 1777 to 26 December 1778. The pledgebook begins in July 1777, but the entries for a number of days are torn or very faint so it was decided to start a comprehensive list from the date when the vast majority of pledges were readily legible.

There were two basic problems attached to this exercise, first relating to changes in customers' circumstances and, second, relating to variation in notation by the pawnbroker or his assistants. Regarding changes of circumstance, it was likely that a number of Fettes's female customers got married during the 17 months under study and changed their surnames, meaning the same individual would be pledging but under two different names; however, it was not thought justifiable to search the marriage registers of York's 28 parishes to identify which women this applied to, and find what their names became. Therefore, the list is likely to overestimate the number of separate female customers. Also, both men and women were able to change address during the same 17 months, but every variation of address in the pledgebook might indicate a different person. Therefore Dorothy Batty, for example, has been counted four times because a woman or women with this name and surname were listed at four different addresses. This is an extreme example but demonstrates how the number of both men and women are probably overestimated.

The second problem concerns the wide variation of spellings enjoyed by different names and the range of possible 'addresses' which might refer to the same location in the city of York. Ruth Creaser lived in Walmgate, but was Ruth Cassia of the same address in fact the same 
woman? It is likely she was, but there was no way to formulate a rule for the conflation of such names. A relational database which compares the extent of correspondence between letters of a name would not have helped much in this instance because there is very little similarity between Creaser and Cassia. Also, the same person might be recorded under different addresses which, on consultation of a map, appear to apply to the same approximate area of the city. William Addy was recorded at Holgate Lane and also living outside Micklegate Bar. The exact location of Holgate Lane is not now known but Holgate was outside Micklegate Bar so it seemed legitimate to conflate the two. Other cases were not so clear-cut.

These difficulties reduce the accuracy of the resulting list to such an extent that the number of 2,200 people reached by these means is little more than an informed guess. Without parish reconstructions for the 28 York city parishes the total picture can never be obtained. Nevertheless, given the number of names in the list which could not conceivably be conflated, the number 2,200 provides a figure to work with to determine approximate proportions of male and female customers, the geographical spread of customers and other calculations.

\section{Notes}

1 York City Archives, pawnbroker's pledgebook, 1777-78.

2 For example, D. Vincent, Poor Citizens (London, Longman, 1991), pp. 92-3.

3 R. Campbell, The London Tradesman (London, T. Gardner, 1747), p. 296.

4 Gentleman's Magazine, xv (1745), p. 410.

$5 \mathrm{~J}$. Stow, Survey of the Cities of London and Westminster ... Corrected, Improved, in the Year 1720 by John Strype (6th edn, London, 1754), I, 474 quoted in B. Lemire, 'Consumerism in preindustrial and early industrial England: the trade in secondhand clothes', Journal of British Studies, 27 (1988), p. 14.

6 A Plain Answer to a late pamphlet intitled The Business of Pawnbroking Stated and Defended (London, W. Bickerton, 1745), p. 4.

7 Ibid., p. 8.

8 J. M. Beattie, Crime and the Courts in England 1660-1800 (Princeton, Princeton University Press, 1986), pp. 189-90.

9 H. Fielding, Amelia (London, Croscup and Sterling Co., 1751), quoted in H. Fielding, An Enquiry into the Late Increase of Robbers (London, 1751), edited by M. Zirker (Oxford, Clarendon, 1988), pp. 125-30.

10 A Plain Answer, pp. 3-4.

11 Gentleman's Magazine, xv (1745), p. 461. 
12 A Plain Answer, pp. 6-7.

13 Ibid., pp. 11, 27; however, it is not impossible that the adult poor actively used children as their intermediaries and messengers.

14 An Apology for the Business of Pawnbroking (London, 1744), p. 57.

15 Gentleman's Magazine, xv (1745), p. 699.

16 Report of Colquhoun's publication of An Account of the Meat and Soup Charity established in the Metropolis, contained in The Times, 20 March 1797 and Gentleman's Magazine, lxvii (1797), pp. 856-7.

17 Pawnbrokers Detected and Dissected: or the poor man's adviser (London, 1809), p. 4.

18 Only J. Bentham, Defence of Usury (London, T. Payne \& Son, 1787) went so far.

19 Pawnbrokers Detected, p. 8.

20 Ibid., p. 44; it is likely that observations of this sort qualify as the misinterpretation of parent/child relations which Pollock has identified when the middle and upper classes tried to comment on the lives of the poor: see L. A. Pollock, Forgotten Children: Parent-Child Relations from 1500 to 1900 (Cambridge, Cambridge University Press, 1983), p. 61 .

21 M. Tebbutt, Making Ends Meet: Pawnbroking and Working-Class Credit (Leicester, Leicester University Press, 1984), p. 3.

22 Gentleman's Magazine, xv (1745), p. 700.

23 Ibid.

24 Tebbutt, Making Ends Meet, p. 13.

$25 \mathrm{~J}$. Lackington, Memoirs of the forty-five first years of the life of James Lackington (London, 1795), pp. 226-7.

26 J.Styles, 'Clothing the North: the supply of non-elite clothing in the eighteenth-century north of England', Textile History, 25 (1994).

27 An Apology; some of the views expressed in this pamphlet had been aired earlier, see Daily Post Boy, 26 April 1731.

28 An Apology, p. 16. There was also some legitimacy in the claim that clothes could depreciate if they went out of fashion. Towards the end of the eighteenth century breeches made of leather were entirely replaced by cloth alternatives such as corduroy, meaning that there was no domestic market for secondhand leather trousers; see Lemire, 'Consumerism', p. 17.

29 An Apology, pp. 16, 26.

30 Gentleman's Magazine, liv (1784), p. 711 reports a case of 1784 where a pawnbroker's apprentice stole jewellery in his master's keeping.

31 J. Black, The English Press in the Eighteenth Century (London, Croom Helm, 1987), p. 60.

32 Gentleman's Magazine, xxii (1752), p. 41.

33 The Public Advertiser, 1 January 1765, quoted in B. Lemire, 'The theft of clothes and popular consumerism in early modern England', Journal of Social History, 24 (1990), p. 259.

34 Campbell, London Tradesman, pp. 296-7. 
35 The Poor Man's Friend, or the Frauds of the Pawnbrokers Exposed (London, H. Chance, c. 1835), pp. 6-7.

36 An Apology, pp. 15-16.

37 Gentleman's Magazine, xxii (1752), p. 284.

3830 Geo 2 c. 24.

3924 Geo 3 c. 42.

40 W. Godwin, The Adventures of Caleb Williams (Oxford, Oxford University Press, 1982), p. 254.

41 B. Lemire, 'Peddling fashion: salesmen, pawnbrokers, taylors, thieves and the second-hand clothes trade in England c. 1700-1800', Textile History, 22, 1 (1991), p. 82.

42 K. Hudson, Pawnbroking: An Aspect of English Social Hhistory (London, Bodley Head, 1982), p. 31.

43 Tebbutt, Making Ends Meet, pp. 3-4.

44 Lemire, 'Consumerism', p. 12.

45 Tebbutt, Making Ends Meet, p. 6.

$46 \mathrm{I}$ am indebted for much of the information contained in this paragraph and the next to the work completed by Alison Backhouse: A. Backhouse, 'The wormeaten waistcoat - the pledge book and owners of a pawnbroker's business', York Historian, 14 (1997).

$47 \mathrm{~J}$. Telford (ed.), The Letters of the Rev. John Wesley (London, Epworth, 1960), VII, p. 77.

48 Ibid., letter of 3 August 1781.

49 D. Defoe, A Tour Through England and Wales (London, J. M. Dent \& Sons, 1959), II, pp. 230, 234.

50 D. M. Palliser, Tudor York (Oxford, Oxford University Press, 1979), p. 1. Drake in 1745, quoted in P. M. Tillott (ed.), Victoria County History for Yorkshire, City of York (London, Dawson for London University Press, 1961), p. 215.

51 A. McInnes, 'The emergence of a leisure town: Shrewsbury 16601760', Past and Present, 120 (1988); W. S. Lewis (ed.), Horace Walpole's Correspondence (New Haven, Yale University Press, 1955), XXVIII, p. 23, letter from William Mason at York dated 21 September 1771 .

52 Tillott, V.C. H. City of York, p. 212; P.P. Abstract of the answers and returns made pursuant to ...' An act for taking an account of the population of Great Britain' (1802).

53 Tillott, V.C.H. City of York, pp. 215-16; York Chronicle, 27 August 1790, quoted in A.Armstrong, Stability and Change in an English County Town: A Social Study of York 1801-1851 (Cambridge, Cambridge University Press, 1974), p. 20.

54 Armstrong, Stability, pp. 27-36.

55 Palliser, Tudor York, p. 280.

56 Drake, quoted in Tillott, V. C. H. City of York, p. 215; P. Slack, Poverty and Policy in Tudor and Stuart England (London, Longman, 1988), p. 72 . 
57 S. Lambert (ed.), House of Commons Sessional Papers of the Eighteenth Century (Wilmington, Delaware, 1975), p. 31 for 'Abstracts of the returns made by the overseers of the poor 1777'; Tillott, V. C. H. City of York, pp. 226-9.

58 York Herald, 30 November 1833.

59 Armstrong, Stability, p. 37.

60 The contents of the pledgebook are ideally suited to conversion to a computer database and this enormous task has been undertaken by Alison Backhouse. The database allows for easy statistical analysis of the numbers of pledges taken, the days of the week most favoured by customers, the types of goods pledged and the values of pawns: see Backhouse, 'Wormeaten waistcoat'. At the time of writing the database is not complete, so findings are based partly on Mrs Backhouse's analysis of pledges July to December 1777 and partly on my own less ambitious databases of the pledgebook contents.

61 Backhouse, 'Wormeaten waistcoat', p. 40.

62 T. S. Ashton, Economic Fluctuations in England 1700-1800 (Oxford, Clarendon, 1959), p. 130.

63 Ibid., p. 23.

64 Ibid., pp. 40, 100, 105, 130, 161-2, 172-3.

65 These two weeks were chosen for two reasons. First, the quality of the accounts is less good at the start of the volume (some pages are torn), but it seemed appropriate to select a period towards the start of the book where the record of redemptions was likely to be fullest. Second, race week occurred in August and pledges made at that time were not necessarily typical because visitors to the town had distant addresses and pledged goods of higher value than usual. Therefore the first two weeks in September 1777 were chosen for close analysis.

66 Backhouse, 'Wormeaten waistcoat', p. 40.

67 Based on the sample of two weeks in September.

68 Tillott, V. C. H. City of York, p. 245.

69 York City Archives, pawnbroker's pledgebook, 19-21 August 1777.

70 For a statistical breakdown of items pledged and an illustrative list of the more unusual pledges taken by Fettes see Backhouse, 'Wormeaten waistcoat', pp. 35-7.

71 B. Lemire, Dress, Culture and Commerce (Basingstoke, Macmillan, 1997), pp. 105-12.

72 My own, rather than that compiled by Mrs Backhouse.

73 This calculation allows customers who were visitors to the town to account for approximately 150 people.

74 Borrowing, like pawning, stands witness to the precariousness of life, where commodities other than cash became effective currency: L. MacKay, 'Why they stole: women in the Old Bailey, 1779-1789', Journal of Social History, 32 (1999), pp.625, 628, 630-4. 
75 Backhouse, 'Wormeaten waistcoat', p. 35.

76 J. H. Treble, Urban Poverty in Britain 1830-1914 (London, Batsford, 1979) p. 132.

77 Lemire, 'Consumerism', p. 23.

78 Treble, Urban Poverty, pp. 131-3.

79 Ibid., p. 133; for an account of a complex, early twentieth-century strategy involving a street moneylender, a credit draper and an established pawnshop, see J. Burnett, Idle Hands: The Experience of Unemployment, 1790-1990 (London, Routledge, 1994), pp. 188-9.

80 Principally, D. Davies, The Case of Labourers in Husbandry (London, Robinson, 1795) and F.M.Eden, The State of the Poor (London, Routledge, 1928), first published 1797; consideration of pawning is largely absent from both of these works. Labourers in husbandry might have had restricted access to urban pawnshops but Eden's trawl of budgets only uncovered one pawnshop customer, a Bristol labourer.

81 An Apology, p. 39.

82 Gentleman's Magazine, xv (1745), p. 697.

83 Campbell, London Tradesman, p. 296.

84 Gentleman's Magazine, xv (1745), pp. 578, 698; Eden, State of the Poor, p. 191.

85 P. King, 'Pauper inventories and the material lives of the poor in the eighteenth and early nineteenth centuries', in T. Hitchcock, P. King and P. Sharpe, Chronicling Poverty: The Voices and Strategies of the English Poor 1640-1840 (Basingstoke, Macmillan, 1997).

86 For instance, there is no mention of this practice in M. Nolan, Treatise on the laws for the relief and settlement of the poor (London, 1805).

87 For example, see Shropshire Records and Research Centre, P250/L/2/1, Shrewsbury Holycross overseers' accounts, workhouse inventory 1750; Borthwick Institute, St Michael le Belfrey workhouse masters' accounts 1744-56, removal of Ann Weatherill's goods to the workhouse, 12 November 1745; Oxford Record Office, Mss dd par Oxford St Peter le Bailey b. 18, redistribution of Elizabeth Cooling's goods 1765; requisitioning of goods was practised more extensively in seventeenth-century London: see J. Boulton, 'Going on the parish: the parish pension and its meaning in the London suburbs, 1640-1724', in Hitchcock et al., Chronicling Poverty, pp. 35-6.

88 P.Anderson, 'The Leeds Workhouse under the Old Poor Law, 1726-1834', Thoresby Miscellany, 17 (Thoresby Society, 1980), pp. 91, 98.

89 J. D. Chambers, Nottinghamshire in the Eighteenth Century (London, Cass, 1966), p. 240.

90 Bailey's Northern Directory (Warrington, William Ashton, 1781).

91 Gentleman's Magazine, xv (1745), pp.460-1.

92 Tillott, V.C. H. City of York, pp. 422-6. 


\section{The poor in England}

93 York City Archives, pawnbroker's pledgebook, 18 July 1777; Backhouse, 'Wormeaten waistcoat', p. 37; B.L. Eg 2572.

94 Northern Directory, p. 317. 